\title{
Effect of Protein Source on Amino Acid Supply, Milk Production, and Metabolism of Plasma Nutrients in Dairy Cows Fed Grass Silage
}

\author{
M. Korhonen, A. Vanhatalo, and P. Huhtanen \\ MTT Agrifood Research Finland \\ Animal Production Research \\ FIN-31600 Jokioinen, Finland
}

\section{ABSTRACT}

This study conducted according to a $4 \times 4$ Latin square with $28 \mathrm{~d}$ periods and four ruminally cannulated Finnish Ayrshire cows investigated the effect of protein supplements differing in amino acid (AA) profile and rumen undegradable protein content on postruminal AA supply and milk production. Mammary metabolism of plasma AA and other nutrients were also studied. The basal diet (Control; $13.4 \%$ crude protein) consisted of grass silage and barley in a ratio of 55:45 on a dry matter basis. The other three isonitrogenous diets (17.0\% crude protein) were control + fishmeal (FM), control + soybean meal (SBM), and control + corn gluten meal (CGM). The protein supplements replaced portions of dry matter of the control diet maintaining the silage to barley ratio constant for all diets. Dry matter intake was limited to $95 \%$ of the preexperimental ad libitum intake and was similar (mean $19.8 \mathrm{~kg} / \mathrm{d}$ dry matter) across the diets. Protein supplements increased milk, lactose, and protein yields but did not affect yields of energy-corrected milk or milk fat. Milk protein yield response was numerically lowest for diet SBM. Protein supplements increased milk protein concentration but decreased milk fat and lactose concentrations. Microbial protein synthesis and rumen fermentation parameters were similar across the diets, except for an increased rumen ammonia concentration for diets supplemented with protein feeds. Protein supplements increased $\mathrm{N}$ intake, ruminal organic matter and $\mathrm{N}$, and total tract organic matter, $\mathrm{N}$, and neutral detergent fiber digestibilities. Protein supplements also increased $\mathrm{N}$ and AA flows into the omasum, with SBM giving the lowest and CGM the highest flows. This was associated with an unchanged microbial $\mathrm{N}$ flow and a higher undegraded dietary $\mathrm{N}$ flow. The omasal flows of individual AA reflected differences in total $\mathrm{N}$ flow and AA profile of the experimental diets. Differences in AA flows did

Received February 28, 2002

Accepted June 26, 2002.

Corresponding author: Mikko Korhonen; e-mail address: mikko. korhonen@mtt.fi. not always reflect plasma AA concentrations. The results indicated that AA supply of dairy cows fed a grass silage-cereal diet can be manipulated using protein supplements differing in ruminal protein degradability and AA profile. Lower milk production response to SBM than that to FM and CGM appeared to be related mainly to lower $\mathrm{N}$ and AA supplies arising from a high ruminal protein degradability of SBM. Histidine appeared to be the first limiting AA for milk protein synthesis on the control diet. Mammary gland may regulate AA uptake according to requirements.

(Key words: amino acid, dairy cow, grass silage, protein)

Abbreviation key: $\mathbf{A V}=$ arteriovenous, $\mathbf{B C A A}=$ branched chain AA, CGM = corn gluten meal, EAA = essential AA, FM = fish meal, $\mathbf{M P S}=$ microbial protein synthesis, NEAA = nonessential AA, SBM = soybean meal, $\mathbf{T A A}=$ total AA, $\mathbf{W S C}=$ water soluble carbohydrate.

\section{INTRODUCTION}

The main sources of metabolizable protein in ruminants are microbial protein synthesized in the rumen and feed protein escaping rumen degradation. On grass silage-cereal-based diets, contribution of microbial protein to postruminal protein flow is usually higher than that of RUP, because of an extensive and rapid degradation of CP of grass silage and cereals in the rumen (Huhtanen, 1998). This, together with differences in AA profiles between corn and alfalfa silage and grass silage, results in different AA supply from the basal diet and a variable ranking of the limiting AA in milk production (Santos et al., 1998; Vanhatalo et al., 1999; Korhonen et al., 2000). The milk production potential of dairy cows has become so high that microbial protein alone is not sufficient to fulfill the protein requirements. Therefore, the diet should be formulated to contain protein supplements that increase rumen bypass protein. Milk and milk protein production responses to increased RUP supply have been inconsistent (Santos et al., 1998). They suggest that lack of enhanced milk production could be associated with a poor AA pattern 
of RUP, i.e., additional protein has not increased the supply of limiting AA for milk protein synthesis. Consequently, in order to enhance milk production, the AA pattern of RUP should be complementary to that of microbial protein. This is further supported by the findings that the effects of dietary changes on AA profiles of individual microbial fractions are negligible (Korhonen et al., 2002b). Lys, Met, and His are the AA that have been studied most extensively. This is because Met and Lys have been first- and/or co-limiting AA on corn and alfalfa silage based diets (Santos et al., 1998) and His on grass silage based diets (Vanhatalo et al., 1999; Kim et al., 2000; Korhonen et al., 2000). The fourth interesting AA is Leu, whose role as the second limiting AA on a grass silage-based diet is unclear (Kim et al., 2001b; Huhtanen et al., 2002; Korhonen et al., $2002 b)$. Compared with most of the protein feeds available, microbial protein is a good source of Lys and Met but not of His (Tuori et al., 2000). Fish meal (FM) is a fairly good source of these three AA, whereas corn gluten meal (CGM) is rich in Leu but is a poor source of Lys. Soybean meal (SBM) may complete His and Lys supplies but has a low Met concentration.

The objective of this study was to examine the effects of AA profile and RUP content of protein supplements on postruminal $\mathrm{N}$ and AA supplies on a grass silagecereal based diet. The effect of diet on milk production parameters, metabolism of protein, plasma AA, and energy metabolites were also investigated.

\section{MATERIALS AND METHODS}

\section{Cows and Feeding}

Four multiparous, rumen-cannulated Finnish Ayrshire cows averaging $51 \mathrm{DIM}(\mathrm{SD}=6)$, and $668 \mathrm{~kg}$ (SD $=109$ ) at the beginning of the study were used. Cows were housed in individual stalls and milked twice daily, at 0700 and $1700 \mathrm{~h}$. Before the actual experiment, the cows were given free access to grass silage and cerealbased concentrate (CP 17.1\%; 33\% barley, 33\% oats, $19 \%$ rapeseed meal, $11 \%$ sugar beet pulp, and $4 \%$ minerals) at a rate of $11 \mathrm{~kg} / \mathrm{d}$ during $1 \mathrm{wk}$ to measure total DMI. In the experiment, the basal diet consisted of fixed amount of grass silage and barley (55:45), and DMI of cows were restricted to $95 \%$ of the preexperimental ad libitum intakes. The amount of feed offered was constant throughout the study, excluding the 1st wk of each period when cows had free access to silage. Feed was given in two equal meals at 0600 and $1800 \mathrm{~h}$, and water was always available. Animals received $300 \mathrm{~g}$ of mineral/vitamin mixture (Viher Hertta-Minera Muro; Suomen Rehu Oy, Helsinki, Finland) daily. It contained $16 \% \mathrm{Ca}, 6.4 \% \mathrm{P}, 9.0 \% \mathrm{Na}, 8.0 \% \mathrm{Mg}, 150,000 \mathrm{IU}$ of vitamin A/kg, 100,000 IU of vitamin D/kg, $950 \mathrm{mg}$ of vitamin
$\mathrm{E} / \mathrm{kg}, 530 \mathrm{mg} / \mathrm{kg}$ of $\mathrm{Cu}, 20 \mathrm{mg} / \mathrm{kg}$ of Se, $4200 \mathrm{mg} / \mathrm{kg}$ of $\mathrm{Zn}, 20 \mathrm{mg} / \mathrm{kg}$ of Mo, $15 \mathrm{mg} / \mathrm{kg}$ of Co, $2250 \mathrm{mg} / \mathrm{kg}$ of Mn, and $140 \mathrm{mg} / \mathrm{kg}$ of $\mathrm{I}$.

Wilted grass silage was prepared from secondary growth of sward containing timothy (Phleum pratense), meadow fescue (Festuca pratensis), and cocksfoot (Dactylis clomerata). Herbage was ensiled in a tower silo using a formic-acid based additive (AIV-2+; applied at a rate of 5L/t grass; Kemira-Agro, Helsinki, Finland).

\section{Experimental Design and Treatments}

The experiment was conducted according to a $4 \times 4$ Latin square design. The length of each experimental period was $28 \mathrm{~d}$, consisting of $14 \mathrm{~d}$ for adaptation, 10 $\mathrm{d}$ for rumen, blood, and milk sampling, and the final 4 $\mathrm{d}$ for total collection of urine and feces and for sampling digesta. Treatments consisted of grass silage and barley (control) fed in a ratio of 55:45 on a DM basis, supplemented with FM, SBM, or CGM. Supplemented diets were formulated to be isonitrogenous $(17.0 \% \mathrm{CP})$, and protein feeds replaced portions of both silage and barley DM such that the ratio of barley to grass silage (55:45; on DM basis) remained constant. The average daily portions of FM, SBM, and CGM were 1.1, 1.8, and 1.2 $\mathrm{kg}$ DM, respectively.

\section{Sampling, Recordings, and Chemical Analyses}

Feed intake and milk production were recorded daily throughout the experiment, and data from the last 14 $d$ of each period were used for statistical analysis. To estimate diet digestibility and nutrient flows, DMI during the collection period was used in the calculation. Feed samples were collected for analysis during each collection period. Details for analyses of chemical compositions of feeds and milk have been described previously (Vanhatalo et al., 1999; Varvikko et al., 1999). Neutral detergent fiber was determined as described by Ahvenjärvi et al. (2000), except that we used an ANKOM 220 FiberAnalyzer (ANKOM Technology, Fairport, NY). Rumen fluid was sampled on d 20 before the morning feeding and 1.5, 3, 4.5, 6, 7.5, and $9 \mathrm{~h}$ thereafter and were analyzed for $\mathrm{pH}, \mathrm{VFA}$, and ammonia as described by Varvikko et al. (1999). Digestibility of diets was determined by total fecal collection on d 24 to 28 with simultaneous collection of urine.

Assessment of the rumen outflow of DM was similar to that described previously (Ahvenjärvi et al., 2000). Indigestible NDF (INDF), Yb, and CoEDTA were used as markers for the large particles, small particles, and liquid phases, respectively. Priming doses of Co-EDTA $(18 \mathrm{~g})$ and $\mathrm{Yb}$-acetate $(6 \mathrm{~g})$ were given at $60 \mathrm{~h}$ prior to the first sampling and were continuously infused (12 
$\mathrm{g} / \mathrm{d}$ of Co-EDTA and $4 \mathrm{~g} / \mathrm{d} \mathrm{Yb}$-acetate) into the rumen thereafter. Digesta samples were collected from the omasum with the device inserted into the omasum through the reticulo-omasal orifice. The samples were prepared and analyzed as described by Ahvenjärvi et al. (2000). The procedure to determine INDF concentration of feeds, digesta, and feces was similar to that described by Ahvenjärvi et al. (2000), with the exception that residues after NDF extraction were ashed. Based on marker concentrations in each phase and mathematically calculated reconstitution factors, omasal digesta was physically composed from the individual fractions for analysis.

Bacterial samples were taken manually from the reticular digesta during the sampling period at 1500 , 1200,0900 , and $0600 \mathrm{~h}$ on sampling $\mathrm{d} 1,2,3$, and 4 , respectively, and ammonium sulfate (Isotec Inc., Miamisburg, OH) with $10 \%$ enrichment of ${ }^{15} \mathrm{~N}\left(250 \mathrm{mg}{ }^{15} \mathrm{~N} /\right.$ $\mathrm{d}$ per cow) was used as a marker to estimate microbial protein flow. Infusion of ${ }^{15} \mathrm{~N}$ was started $48 \mathrm{~h}$ before the first sampling. Preparations of samples were as described by Ahvenjärvi et al. (2000), and measurement of ${ }^{15} \mathrm{~N}$ enrichment, and calculation for microbial protein flow were similar to those reported by Ahvenjärvi et al. (2002). Amino acids from feeds, digesta, and bacterial samples were analyzed as described by Korhonen et al. (2000).

Blood samples were taken into Li-EDTA (for AA, glucose, NEFA, and BHBA analysis) and into Li-Heparin (for acetic acid analysis) tubes (Vacuette, Greiner Labortechnik, GmbH, Krensmünster, Austria) from one superficial epigastric (mammary) vein, considered to be venous blood, and one coccygeal (tail) vessel, considered to be arterial blood, at 0600,0900 , and 1200 on d 20 of each period. Tubes were placed into an ice bath and centrifuged (at $872 \mathrm{~g}$ and $4^{\circ} \mathrm{C}$ for $15 \mathrm{~min}$ ) immediately after sampling. For analysis, both arterial and venous plasma were pooled across sampling times to provide one sample of both per cow. Analyses of AA, glucose, BHBA, NEFA, insulin, and acetic acid from plasma samples have been described previously (Korhonen et al., 2002a).

\section{Calculations and Statistical Analyses}

Assessment of mammary plasma flow, extractions, arteriovenous (AV) differences, and mammary uptakes of AA have been described elsewhere (Korhonen et al., 2000). Briefly, mammary plasma flow was estimated by reference to Phe and Tyr output in milk protein by the application of Fick principle. Milk free Phe and Tyr were neglected, and it was assumed that they are incorporated directly into milk protein without further metabolism or synthesis. Extraction and mammary up- take values were calculated as AV difference/arterial concentration and $\mathrm{AV}$ difference $\times$ mammary plasma flow, respectively. Postruminal flows of OM, NDF, NAN, and AA were calculated based on DM flow and concentrations of $\mathrm{OM}, \mathrm{NDF}, \mathrm{NAN}$, and $\mathrm{AA}$ in digesta samples.

Data were analyzed with the GLM procedure of SAS (1996) according the following statistical model: $\mathrm{Y}_{\mathrm{ijk}}=$ $\mu+\mathrm{A}_{\mathrm{i}}+\mathrm{P}_{\mathrm{j}}+\mathrm{D}_{\mathrm{k}}+\mathrm{e}_{\mathrm{ijk}}$, where A, P, and D are animal, period and diet effects. Rumen fermentation data were analyzed as repeated measurements using MIXED procedure of SAS. Sums of squares were further divided into orthogonal contrasts. The comparisons were control vs. others (effect of protein supplementation; C1), FM vs. SBM + CGM (animal versus plant proteins; C2), and SBM vs. CGM (comparison of plant proteins; C3). Differences were considered significant at $P \leq 0.05$, and tendencies were noted for $P \leq 0.10$.

\section{RESULTS}

\section{DMI and Milk Production}

Chemical composition of feedstuffs is shown in Table 1 , and intake and milk production data in Table 2. Grass silage was of high quality both in terms of nutrient content and fermentation characteristics. High content of residual sugars and low amounts of fermentation acids as well as ammonia $\mathrm{N}$ indicated restricted fermentation in the silo. In vitro digestibility of silage $\mathrm{OM}$ was also high. Statistical analysis on feed intake is not reported because cows received the restricted amount of feeds ( $95 \%$ of the preexperimental ad libitum intake), and daily portions of feeds for individual cows were maintained constant throughout the study. The cows consumed $19.8 \mathrm{~kg} \mathrm{DM} / \mathrm{d}$ on average, of which $46 \%$ was concentrate. The silage to barley ratio across the treatments was 58:42 and was not different for the treatments. Crude protein contents of the ingested diets were $13 \%, 16.2 \%, 16 \%$, and $16 \%$ for diets control, FM, SBM, and CGM, respectively. Estimates of absorbed AA supplies relative to requirements, based on Finnish feeding recommendation and feed tables (Tuori et al., 2000 ), were $110 \%, 119 \%, 121 \%$, and $120 \%$ for diets control, FM, SBM, and CGM. The respective values for energy were $108 \%, 107 \%, 112 \%$, and $105 \%$ in the same order.

Compared to the control diet, protein supplements increased $(P<0.01)$ milk, milk protein, and milk lactose yields, and CGM supplementation resulted in higher $(P<0.05)$ protein yield than SBM supplementation. Protein supplements also increased $(P<0.05)$ milk protein and urea concentrations but decreased $(P<0.05)$ concentrations of milk fat and milk lactose. Milk lactose 
Table 1. Chemical composition of feedstuffs and diets.

\begin{tabular}{|c|c|c|c|c|c|c|}
\hline & $\begin{array}{l}\text { Grass } \\
\text { silage }\end{array}$ & Barley & $\begin{array}{l}\text { Soybean } \\
\text { meal }\end{array}$ & $\begin{array}{l}\text { Fish } \\
\text { meal }\end{array}$ & $\begin{array}{l}\text { Corn } \\
\text { gluten } \\
\text { meal }\end{array}$ & $\begin{array}{l}\text { Rumen } \\
\text { bacteria }\end{array}$ \\
\hline $\mathrm{pH}$ & 4.00 & & & & & \\
\hline $\mathrm{DM}, \%$ & 22.2 & 88.8 & 91.2 & 90.9 & 91.7 & \\
\hline Ash & 8.6 & 2.7 & 6.0 & 11.9 & 3.1 & \multirow[t]{9}{*}{21.1} \\
\hline NDF & 50.6 & 18.9 & 11.2 & 13.4 & 6.0 & \\
\hline $\mathrm{ADF}$ & 25.7 & 3.9 & 5.9 & 0 & 0.7 & \\
\hline INDF & 8.0 & 3.9 & 0.17 & 2.1 & 0.39 & \\
\hline Water-soluble carbohydrates & 14.6 & & & & & \\
\hline Lactic acid & 1.22 & & & & & \\
\hline Acetic acid & 0.98 & & & & & \\
\hline Butyric acid & 0.01 & & & & & \\
\hline $\mathrm{OM}$ in vitro cellulase digestibility, $\%$ & 77 & & & & & \\
\hline Total N & 2.1 & 2.2 & 7.5 & 12.2 & 10.8 & 6.9 \\
\hline \multicolumn{7}{|l|}{ Soluble $\mathrm{N}$ fractions, $\%$ of total $\mathrm{N}^{1}$} \\
\hline NPN & 45.3 & 12.6 & 4.2 & 10.7 & 6.1 & \\
\hline \multirow[t]{2}{*}{$\mathrm{B}_{1}$} & 1.5 & 15.1 & 16.3 & 8.0 & 0.9 & \\
\hline & \multicolumn{6}{|c|}{ g/100 g AA } \\
\hline Arg & 6.0 & 5.3 & 7.4 & 7.1 & 3.1 & 4.8 \\
\hline His & 2.6 & 2.5 & 2.8 & 2.6 & 1.9 & 2.1 \\
\hline Ile & 5.1 & 4.0 & 4.7 & 4.6 & 3.6 & 5.5 \\
\hline Leu & 9.2 & 7.2 & 8.1 & 8.6 & 15.9 & 7.8 \\
\hline Lys & 5.4 & 3.8 & 6.6 & 8.3 & 1.6 & 7.0 \\
\hline Met & 2.5 & 1.8 & 1.4 & 3.0 & 1.9 & 3.0 \\
\hline Phe & 6.3 & 5.5 & 5.3 & 4.3 & 5.8 & 5.2 \\
\hline Thr & 5.3 & 3.7 & 4.0 & 4.7 & 3.2 & 5.5 \\
\hline Val & 6.6 & 6.7 & 5.0 & 5.5 & 6.2 & 6.0 \\
\hline
\end{tabular}

${ }^{1}$ Nitrogen fractions are reported in more detail by Choi et al. (2002).

Table 2. Least squares means for feed intake, milk yield, and milk composition.

\begin{tabular}{|c|c|c|c|c|c|c|c|c|}
\hline & \multicolumn{4}{|c|}{ Diets $^{1}$} & \multirow[b]{2}{*}{ SEM } & \multicolumn{3}{|c|}{ Orthogonal contrasts ${ }^{2}$} \\
\hline & Control & FM & SBM & CGM & & 1 & 2 & 3 \\
\hline \multicolumn{9}{|l|}{$\mathrm{DMI}, \mathrm{kg} / \mathrm{d}$} \\
\hline Silage & 11.2 & 10.7 & 10.2 & 10.6 & 0.11 & & & \\
\hline Concentrate & 8.6 & 9.1 & 9.5 & 9.1 & 0.21 & & & \\
\hline Total & 19.8 & 19.8 & 19.7 & 19.7 & 0.16 & & & \\
\hline \multicolumn{9}{|l|}{ Yield, kg/d } \\
\hline Milk & 23.1 & 26.4 & 26.1 & 27.0 & 0.58 & ** & NS & NS \\
\hline $\mathrm{ECM}^{3}$ & 26.6 & 28.6 & 27.3 & 28.6 & 0.79 & NS & NS & NS \\
\hline Protein, g/d & 788 & 945 & 901 & 953 & 14.3 & $* * *$ & NS & $*$ \\
\hline Lactose, g/d & 1137 & 1276 & 1277 & 1294 & 32.9 & $* *$ & NS & NS \\
\hline Fat, g/d & 1178 & 1181 & 1108 & 1169 & 47.4 & NS & NS & NS \\
\hline \multicolumn{9}{|c|}{ Milk composition, $\%$ of milk } \\
\hline Protein & 3.40 & 3.60 & 3.54 & 3.54 & 0.050 & * & NS & NS \\
\hline Lactose & 4.90 & 4.82 & 4.87 & 4.78 & 0.022 & * & NS & $*$ \\
\hline Fat & 5.05 & 4.45 & 4.29 & 4.35 & 0.136 & ** & NS & NS \\
\hline Urea, mg/L & 127 & 272 & 266 & 263 & 10.0 & $* * *$ & NS & NS \\
\hline
\end{tabular}

${ }^{1}$ Control = silage + barley. $\mathrm{FM}=$ silage + barley + fishmeal. $\mathrm{SBM}=$ silage + barley + soybean meal. CGM $=$ silage + barley + corn gluten meal.

${ }^{2} 1=$ control vs others. $2=$ FM vs SBM + CGM. $3=$ SBM vs CGM.

${ }^{3} \mathrm{ECM}=$ Energy-corrected milk; calculated as: $(383 \times$ fat $\%+242 \times$ protein $\%+165.4 \times$ lactose $\%+20.7) /$ 3140 .

$* P \leq 0.05$.

$* * P \leq 0.01$.

$* * * P \leq 0.001$ 
KORHONEN ET AL.

Table 3. Least squares means for rumen fermentation parameters and diet digestibility.

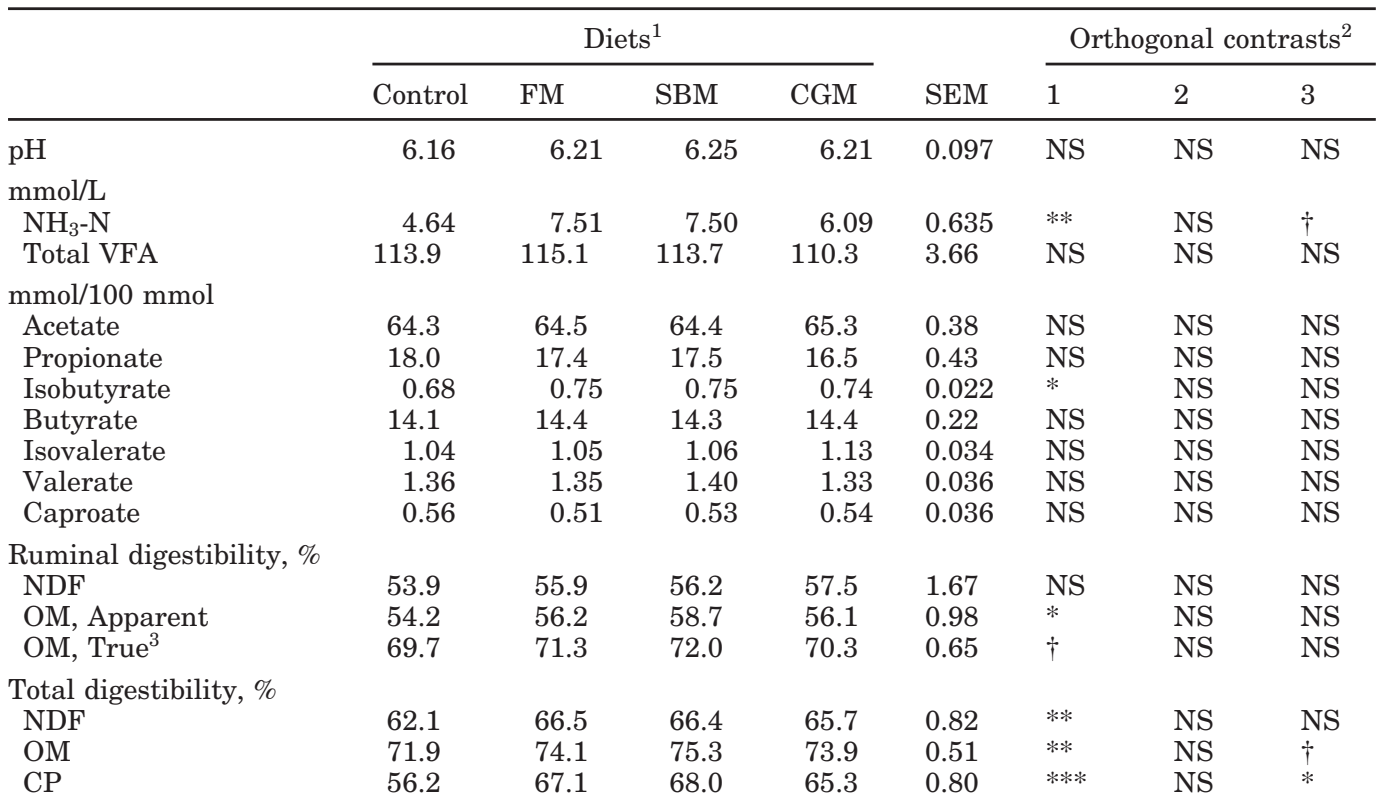

${ }^{1}$ Control $=$ silage + barley. $\mathrm{FM}=$ silage + barley + fishmeal. $\mathrm{SBM}=$ silage + barley + soybean meal. $\mathrm{CGM}$ $=$ silage + barley + corn gluten meal .

${ }^{2} 1=$ control vs others. $2=$ FM vs SBM + CGM. $3=$ SBM vs CGM

${ }^{3}$ Dietary OM flow $=$ total OM flow - microbial OM flow.

$\dagger P \leq 0.10$.

$* P \leq 0.05$.

$* * P \leq 0.01$

concentration was lower $(P<0.05)$ for diet supplemented with CGM than that supplemented with SBM.

\section{Rumen Fermentation and Digestibilities of Feed Constituents}

Rumen fermentation parameters and digestibilities of OM and NDF are shown in Table 3. Molar proportion of isobutyrate and rumen ammonia concentration were $(P<0.05)$ higher for supplemented diets than for the control diet, and rumen ammonia concentration tended $(P=0.06)$ to be higher for diet SBM than for diet CGM. Ruminal NDF digestibility was similar $(P>0.10)$ across the diets but protein supplements increased $(P<0.05)$ apparent ruminal $\mathrm{OM}$, and tended to $(P=0.09)$ increase true ruminal OM digestibilities. Total tract $\mathrm{OM}, \mathrm{CP}$, and NDF digestibilities increased $(P<0.01)$ as well for supplemented diets compared to the control diet, and SBM led to a greater increase in $\mathrm{N}$ digestibility $(P<$ $0.05)$ and tended to lead to a greater increase in $\mathrm{OM}$ $(P=0.10)$ digestibility than CGM.

\section{Nitrogen and AA Supplies}

Only the mean AA profile of rumen bacteria across the diets is shown in Table 1 , since dietary treatments did not affect $(P>0.10)$ AA profile of rumen bacteria. Amino acid profiles of feedstuffs are also shown in Table 1. Dietary effects on $\mathrm{N}$ intake and omasal flows of $\mathrm{N}$ fractions are shown in Table 4. Compared to the control diet, protein supplements increased $(P<0.05) \mathrm{N}$ intake as well as total NAN flow into the omasum. Despite the similar $(P>0.10) \mathrm{N}$ intake for the supplemented diets, omasal total NAN and dietary NAN flows were lower $(P<0.05)$ for diet SBM than for diet CGM. Increased NAN flow was of dietary origin, since microbial NAN flow was similar $(P>0.10)$ across the treatments. Protein supplements increased $(P<0.05)$ urinary $\mathrm{N}$ excretion and tended $(P=0.08)$ to decrease fecal $\mathrm{N}$ excretion. Ruminal apparent and total tract digestibilities of $\mathrm{N}$ were higher $(P<0.05)$ for supplemented diets than for the control diet, whereas true ruminal $\mathrm{N}$ digestibility was $(P<0.05)$ higher for the control diet. Soybean meal supplementation increased more $(P<0.05)$ ruminal $\mathrm{N}$ digestibility than CGM supplementation.

Omasal AA flows are shown in Table 5. Protein supplements increased $(P<0.05)$ or tended $(P<0.10)$ to increase the flow of 12 out of 17 AA studied, also increasing flows of branched chain AA (BCAA), essential AA (EAA), nonessential AA (NEAA), and total AA (TAA). Compared to diet FM, Lys, and Met flows were lower $(P<0.05)$ and that of $\operatorname{Arg}$ tended to be lower $(P=0.08)$, 
Table 4. Least squares means for omasal $\mathrm{N}$ flow and $\mathrm{N}$ digestibility.

\begin{tabular}{|c|c|c|c|c|c|c|c|c|}
\hline & \multicolumn{4}{|c|}{$\operatorname{Diets}^{1}$} & \multirow[b]{2}{*}{ SEM } & \multicolumn{3}{|c|}{ Orthogonal contrasts } \\
\hline & Control & FM & SBM & CGM & & 1 & 2 & 3 \\
\hline Intake, g/d & 403 & 501 & 511 & 496 & 6.9 & $* * *$ & NS & NS \\
\hline \multicolumn{9}{|l|}{ In omasum, $\mathrm{g} / \mathrm{d}$} \\
\hline Total NAN & 358 & 396 & 368 & 413 & 11.2 & $*$ & NS & * \\
\hline Dietary NAN & 112 & 164 & 142 & 192 & 4.6 & $* * *$ & NS & $* * *$ \\
\hline Microbial NAN & 246 & 232 & 226 & 221 & 9.5 & NS & NS & NS \\
\hline $\mathrm{N}$ in feces, $\mathrm{g} / \mathrm{d}$ & 177 & 165 & 163 & 172 & 4.2 & $\dagger$ & NS & NS \\
\hline $\mathrm{N}$ in urine, $\mathrm{g} / \mathrm{d}$ & 103 & 174 & 169 & 156 & 7.9 & $* * *$ & NS & NS \\
\hline \multicolumn{9}{|c|}{ Ruminal N digestibility, \% } \\
\hline Apparent & 11.0 & 21.1 & 28.7 & 16.6 & 3.58 & * & NS & * \\
\hline True $^{3}$ & 72.2 & 67.4 & 72.5 & 61.2 & 1.06 & $* *$ & NS & $* * *$ \\
\hline True $^{4}$ & 75.1 & 69.6 & 74.7 & 63.4 & 1.03 & $* *$ & NS & $* * *$ \\
\hline \multicolumn{9}{|c|}{ Microbial N synthesis } \\
\hline g N/kg OMADR ${ }^{5}$ & 25.7 & 23.2 & 20.9 & 22.6 & 1.78 & NS & $\mathrm{NS}$ & NS \\
\hline g N/kg OMTDR 6 & 19.8 & 18.2 & 16.9 & 17.6 & 1.04 & NS & NS & NS \\
\hline $\mathrm{N}$ balance, $\mathrm{g} / \mathrm{d}$ & 1.2 & 18.7 & 40.1 & 19.9 & 10.62 & NS & NS & NS \\
\hline
\end{tabular}

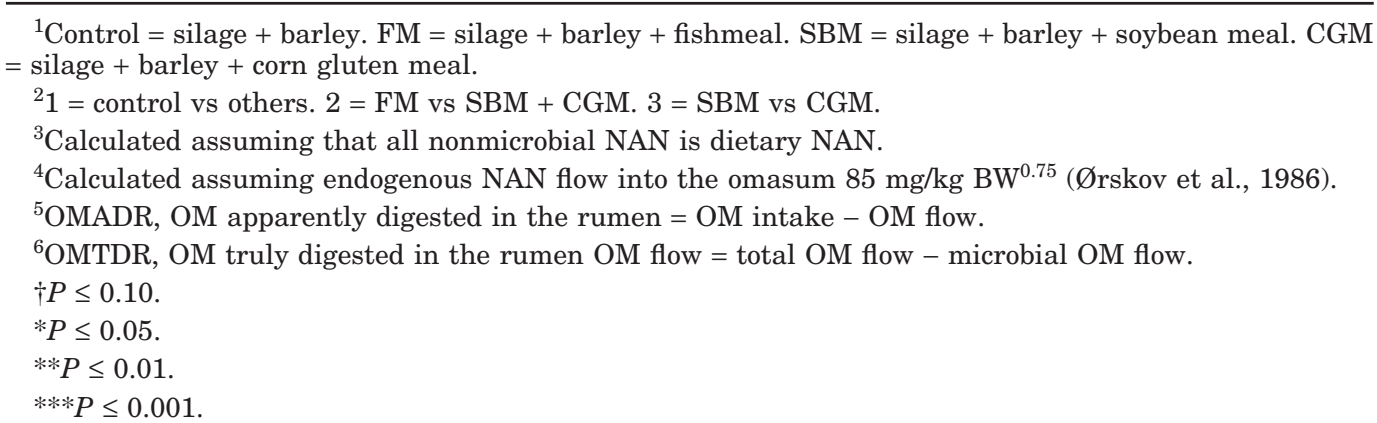

whereas flows Cys, Glu, and Pro were higher $(P<0.05)$ for diets SBM and CGM. Soybean meal supplementation decreased $(P<0.05)$ the flows of 10 out of $17 \mathrm{AA}$ studied and also the flows of BCAA, EAA, NEAA, and TAA compared with CGM supplementation.

\section{Plasma AA and Other Metabolites}

Amino acids. Arterial plasma concentrations of AA are shown in Table 6. Protein supplements increased $(P<0.05)$ arterial concentrations of BCAA and most of EAA, except for Met, Thr, and Trp. Of the NEAA, protein supplements increased $(P<0.05)$ Cys and Pro concentrations and decreased $(P<0.05)$ Glu concentration. Concentrations of Lys and Met were higher $(P<0.05)$, that of Ile tended $(P=0.07)$ to be higher, and concentrations of Leu, Phe, and Pro were higher $(P<0.05)$ for diet FM than for diets SBM and CGM. Concentrations of Arg, Ile, Lys, Trp, and Cys were higher $(P<0.05)$, that of Val tended $(P=0.09)$ to be higher, and concentrations of Leu, Phe, Pro, and Tyr were $(P<0.05)$ lower for diet SBM compared with diet CGM.

Arteriovenous differences of AA are shown in Table 7. Protein supplements increased $(P<0.05)$ or tended $(P<0.10)$ to increase AV differences of most EAA, except for Met, Thr, and Trp. This together with increased $(P$
$<0.01)$ AV differences of Gln and Ser was responsible for higher AV differences of NEAA and TAA for supplemented diets than for the control diet. Arteriovenous differences of Arg, Leu, Val, Tyr, BCAA $(P<0.01)$, and EAA $(P<0.05)$ were lower, and those of Ile $(P=0.08)$, Phe $(P=0.07)$, and TAA $(P=0.09)$ tended to be lower for diet FM than for diets SBM and CGM. Arteriovenous differences of Arg and Trp were higher $(P<0.05)$, those of Gln $(P=0.10)$ and Gly $(P=0.09)$ tended to be higher, and that of Leu was $(P<0.05)$ lower for diet SBM than for diet CGM.

Mammary extractions of AA are shown in Table 8. Protein supplements increased extractions of NEAA, TAA, Ile, Phe, Ser $(P<0.05)$, Gln $(P<0.001)$, and Tyr $(P<0.01)$, and decreased $(P<0.01)$ extraction of Leu. Extractions of Arg, Lys, EAA $(P<0.05)$, Ile, Val, and BCAA $(P<0.01)$ were lower; that of Met tended to be $(P=0.07)$ lower; and that of Tyr tended to be $(P=$ 0.08) higher for diet FM than for diets SBM and CGM. Extractions of Ile $(P<0.01)$, Lys, and Glu $(P<0.05)$ were lower; extraction of Leu was higher $(P<0.01)$; and those of $\operatorname{Trp}(P=0.06)$ and $\operatorname{Tyr}(P=0.09)$ tended to be higher for diet SBM than for diet CGM.

Mammary uptakes of AA are shown in Table 9. Uptakes of BCAA $(P<0.001)$, EAA $(P<0.01)$, and TAA $(P<0.05)$ were higher and that of NEAA tended $(P=$ 
KORHONEN ET AL.

Table 5. Least squares means for omasal AA flow (g/d).

\begin{tabular}{|c|c|c|c|c|c|c|c|c|}
\hline \multirow[b]{2}{*}{$\mathrm{AA}^{3}$} & \multicolumn{4}{|c|}{$\operatorname{Diets}^{1}$} & \multirow[b]{2}{*}{ SEM } & \multicolumn{3}{|c|}{ Orthogonal contrasts ${ }^{2}$} \\
\hline & Control & FM & SBM & CGM & & 1 & 2 & 3 \\
\hline Arg & 77.5 & 92.2 & 85.7 & 83.9 & 2.83 & $*$ & $\dagger$ & NS \\
\hline His & 36.1 & 41.7 & 38.3 & 42.1 & 1.15 & $* *$ & NS & $\dagger$ \\
\hline Ile & 93.1 & 105.8 & 97.4 & 106.0 & 3.69 & $\dagger$ & NS & NS \\
\hline Leu & 129.8 & 151.4 & 139.6 & 204.0 & 4.74 & $* * *$ & $* *$ & $* * *$ \\
\hline Lys & 103.9 & 126.1 & 108.8 & 102.6 & 4.70 & NS & $* *$ & NS \\
\hline Met & 45.6 & 52.7 & 44.1 & 51.2 & 1.62 & $\dagger$ & $*$ & $*$ \\
\hline Phe & 89.8 & 87.4 & 80.7 & 98.5 & 2.72 & $* *$ & NS & $* *$ \\
\hline Thr & 86.5 & 97.0 & 88.0 & 94.2 & 3.51 & NS & NS & $\mathrm{NS}$ \\
\hline Val & 103.6 & 113.8 & 109.0 & 120.2 & 5.19 & NS & NS & NS \\
\hline Ala & 107.8 & 122.4 & 109.0 & 141.0 & 4.46 & $*$ & NS & $* *$ \\
\hline Asp & 180.8 & 203.1 & 193.4 & 196.2 & 7.84 & NS & NS & NS \\
\hline Cys & 23.9 & 24.9 & 25.2 & 29.0 & 0.72 & $*$ & $*$ & $* *$ \\
\hline Glu & 212.2 & 238.4 & 240.0 & 292.8 & 8.31 & $* *$ & $*$ & $* *$ \\
\hline Gly & 89.2 & 98.4 & 91.7 & 93.6 & 3.04 & NS & NS & NS \\
\hline Pro & 81.4 & 88.9 & 89.7 & 119.8 & 3.01 & $* *$ & $* *$ & $* * *$ \\
\hline Ser & 74.3 & 83.1 & 80.4 & 93.2 & 2.56 & $* *$ & NS & $* *$ \\
\hline Tyr & 81.3 & 87.4 & 80.7 & 98.5 & 2.72 & $*$ & NS & $* *$ \\
\hline BCAA & 327 & 371 & 346 & 430 & 12.7 & $* *$ & NS & $* *$ \\
\hline EAA & 766 & 879 & 804 & 916 & 27.8 & $*$ & NS & $*$ \\
\hline NEAA & 851 & 945 & 910 & 1064 & 27.9 & $* *$ & NS & $* *$ \\
\hline TAA & 1617 & 1825 & 1714 & 1980 & 55.0 & $* *$ & NS & $* *$ \\
\hline TAA, \% of CP & 72.2 & 74.7 & 73.8 & 77.3 & 0.88 & $*$ & NS & $*$ \\
\hline
\end{tabular}

$0.10)$ to be higher for diets supplemented with protein feeds compared with the control diet. These were due to increased uptakes of His $(P<0.05)$, Ile, Leu, Gln $(P$ $<0.01)$, and Ser $(P<0.05)$. Uptakes of Leu, and BCAA $(P<0.01)$ were lower, uptakes of $\operatorname{Asp}(P=0.10)$ and Glu $(P=0.07)$ tended to be lower, and uptake of Lys $(P$ $<0.05$ ) was higher for diet FM than for diets SBM and CGM. Uptake of Leu was $(P<0.01)$ higher, that of BCAA tended $(P=0.07)$ to be higher, and that of Trp was $(P<0.05)$ lower for diet SBM than for diet CGM.

Mammary plasma flow, and plasma energy metabolites, urea, and insulin. Mammary plasma flow, arterial plasma concentrations, AV differences, extractions, and mammary uptakes of energy metabolites, and arterial plasma concentrations of urea and insulin are shown in Table 10. Protein supplements decreased $(P<0.05)$ mammary plasma flow, which tended $(P=$ $0.06)$ to be higher for diet FM than for diets SBM and CGM. Protein supplements decreased $(P<0.05)$ plasma glucose concentration and tended $(P=0.08)$ to increase extraction of glucose. Mammary uptake of glucose tended $(P=0.07)$ to be higher for diet FM than for diets
SBM and CGM. Dietary treatments had no effect $(P>$ 0.10 ) on arterial concentrations, AV differences, extractions or mammary uptakes of NEFA, BHBA, and acetate. Protein supplements tended $(P=0.06)$ to decrease plasma insulin concentration, and increased $(P<0.001)$ plasma urea concentration which tended $(P=0.10)$ to be lower for diet CGM than for diet SBM.

\section{DISCUSSION}

\section{DMI and Milk Production}

The fermentation quality of grass silage as indicated by a high concentration of WSC and a low concentration of lactate was comparable to silages ensiled with an application of formic acid (Miettinen and Huhtanen, 1997; Heikkilä et al., 1998). Higher WSC content of our silages compared with silages generally reported is probably associated with a high content of WSC in fresh herbage and a high application rate of formic acid (from 5 to $6.5 \mathrm{~L} / \mathrm{t}$ grass) used in Finland, since formic acid inhibits the natural fermentation of WSC to lactate. 
Table 6. Least squares means for arterial plasma AA concentrations ( $\mu \mathrm{mol} / \mathrm{L})$.

\begin{tabular}{|c|c|c|c|c|c|c|c|c|}
\hline \multirow[b]{2}{*}{$\mathrm{AA}^{3}$} & \multicolumn{4}{|c|}{$\operatorname{Diets}^{1}$} & \multirow[b]{2}{*}{ SEM } & \multicolumn{3}{|c|}{ Orthogonal contrasts $^{2}$} \\
\hline & Control & FM & SBM & CGM & & 1 & 2 & 3 \\
\hline Arg & 53.7 & 80.0 & 80.3 & 55.7 & 5.54 & $*$ & NS & $*$ \\
\hline His & 12.1 & 21.9 & 36.1 & 25.4 & 5.30 & * & NS & NS \\
\hline Ile & 82.6 & 111.5 & 113.2 & 82.5 & 5.17 & $*$ & $\dagger$ & $* *$ \\
\hline Leu & 68.9 & 92.6 & 98.8 & 156.3 & 4.96 & $* * *$ & $* * *$ & $* * *$ \\
\hline Lys & 62.2 & 101.9 & 91.9 & 60.7 & 4.69 & $* *$ & $* *$ & $* *$ \\
\hline Met & 21.8 & 25.3 & 20.0 & 19.8 & 1.70 & NS & $*$ & NS \\
\hline Phe & 47.6 & 37.7 & 46.3 & 51.5 & 0.84 & $*$ & $* * *$ & $* *$ \\
\hline Thr & 112.1 & 108.4 & 105.5 & 92.1 & 10.19 & NS & NS & NS \\
\hline Trp & 40.6 & 38.8 & 41.9 & 31.0 & 1.63 & NS & NS & $* *$ \\
\hline Val & 139.0 & 186.4 & 191.9 & 160.2 & 11.04 & $*$ & NS & $\dagger$ \\
\hline $\mathrm{Ala}$ & 260.5 & 264.2 & 261.6 & 248.8 & 20.60 & NS & NS & NS \\
\hline Asn & 60.4 & 62.7 & 66.3 & 61.8 & 4.09 & NS & NS & NS \\
\hline Asp & 5.8 & 6.2 & 6.0 & 5.3 & 0.29 & NS & NS & NS \\
\hline Cys & 15.8 & 26.1 & 26.0 & 22.7 & 0.88 & $* * *$ & NS & $*$ \\
\hline Gln & 320.3 & 309.3 & 309.5 & 287.0 & 16.96 & NS & NS & NS \\
\hline Glu & 47.2 & 42.9 & 40.3 & 38.4 & 2.22 & $*$ & NS & NS \\
\hline Gly & 389.0 & 336.7 & 342.5 & 310.5 & 28.47 & NS & NS & NS \\
\hline Pro & 70.5 & 96.6 & 95.4 & 129.6 & 4.92 & $* * *$ & $*$ & $* *$ \\
\hline Ser & 139.8 & 115.3 & 119.2 & 121.9 & 12.51 & NS & NS & NS \\
\hline Tyr & 54.5 & 42.5 & 49.2 & 60.8 & 3.45 & NS & NS & $*$ \\
\hline BCAA & 290 & 390 & 404 & 399 & 20.6 & $*$ & NS & NS \\
\hline EAA & 641 & 804 & 826 & 735 & 40.3 & * & NS & NS \\
\hline NEAA & 1363 & 1302 & 1316 & 1287 & 83.5 & NS & NS & NS \\
\hline TAA & 2004 & 2107 & 2142 & 2022 & 117.7 & NS & NS & NS \\
\hline
\end{tabular}

${ }^{1}$ Control $=$ silage + barley. $\mathrm{FM}=$ silage + barley + fishmeal. $\mathrm{SBM}=$ silage + barley + soybean meal. CGM $=$ silage + barley + corn gluten meal.

${ }^{2} 1=$ control vs others. $2=$ FM vs SBM + CGM. $3=$ SBM vs CGM.

${ }^{3} \mathrm{BCAA}=$ Branched chain AA (Val, Ile, and Leu). EAA = Essential AA (Arg, His, Ile, Leu, Lys, Met, Phe, Thr, Trp, and Val). NEAA = Nonessential AA (Ala, Asn, Asp, Cys, Gln, Glu, Gly, Pro, Ser, and Tyr). TAA $=$ Essential AA + Nonessential AA.

$\dagger P \leq 0.10$.

$* P \leq 0.05$.

$* * P \leq 0.01$.

$* * * P \leq 0.001$.

The daily portions of feed offered to individual cows were kept constant throughout the study, and no differences in DMI between the treatments were expected. Because DMI was similar across the treatments (Table 2), cows consumed all feeds with no refusals. Similar $\mathrm{N}$ intake and silage to barley ratio for the supplemented diets confirmed that the only difference between the dietary treatments was the source of supplementary protein.

Compared with other studies carried out with a grass silage based diet, responses (increase in yield/increase in CP intake; g/g) to FM in milk yield (5.1) and in milk protein yield (0.24) were consistent with those (from 2.5 to 6.0 and from 0.08 to 0.24 ; dietary CP content from $12.1 \%$ to $12.9 \%$ ) reported by Chamberlain et al. (1989) but higher than those (1.4 and 0.08; dietary CP content of $15.2 \%$ ) reported by Heikkilä et al. (1998). In the case of SBM, responses in milk yield (5.0) and milk protein yield (0.19) were higher than those (from 1.5 to 3.8 and from 0.08 to 0.15 ) reported by Chamberlain et al. (1989). Kim et al. (2001b) observed similar protein yield response (0.17) and a lower milk yield response (2.15) with dietary CP content of $16 \%$. In contrast to the responses mentioned above, milk and milk protein yields were unaffected by FM or SBM supplementations with dietary CP content of $12.9 \%$ (Sloan et al., 1988).

Responses to supplementations of FM (from 0.05 to $0.23)$ and SBM (0.09 to 0.18$)$ in milk protein yield as well as in milk yield (from 1.83 to 8.2 for FM and from 1.56 to 5.7 for SBM) have also been variable in corn and alfalfa silage based diets (Spain et al., 1990; Wohlt et al., 1991; Broderick, 1992). In these studies, CP content of the basal diet varied between 12 and $16.1 \%$.

Supplementation of the basal diet with CGM resulted in numerically higher milk and milk protein yield responses (6.6 and 0.28) than FM or SBM supplementations. These responses were also higher than the respective values for CGM on corn and alfalfa silage based diets (5.1 and 0.13; Wohlt et al., 1991). In contrast, Spain et al. (1990) did not get any responses to CGM compared to basal diets containing less CP. 
KORHONEN ET AL.

Table 7. Least squares means for arteriovenous differences of AA ( $\mu \mathrm{mol} / \mathrm{L})$.

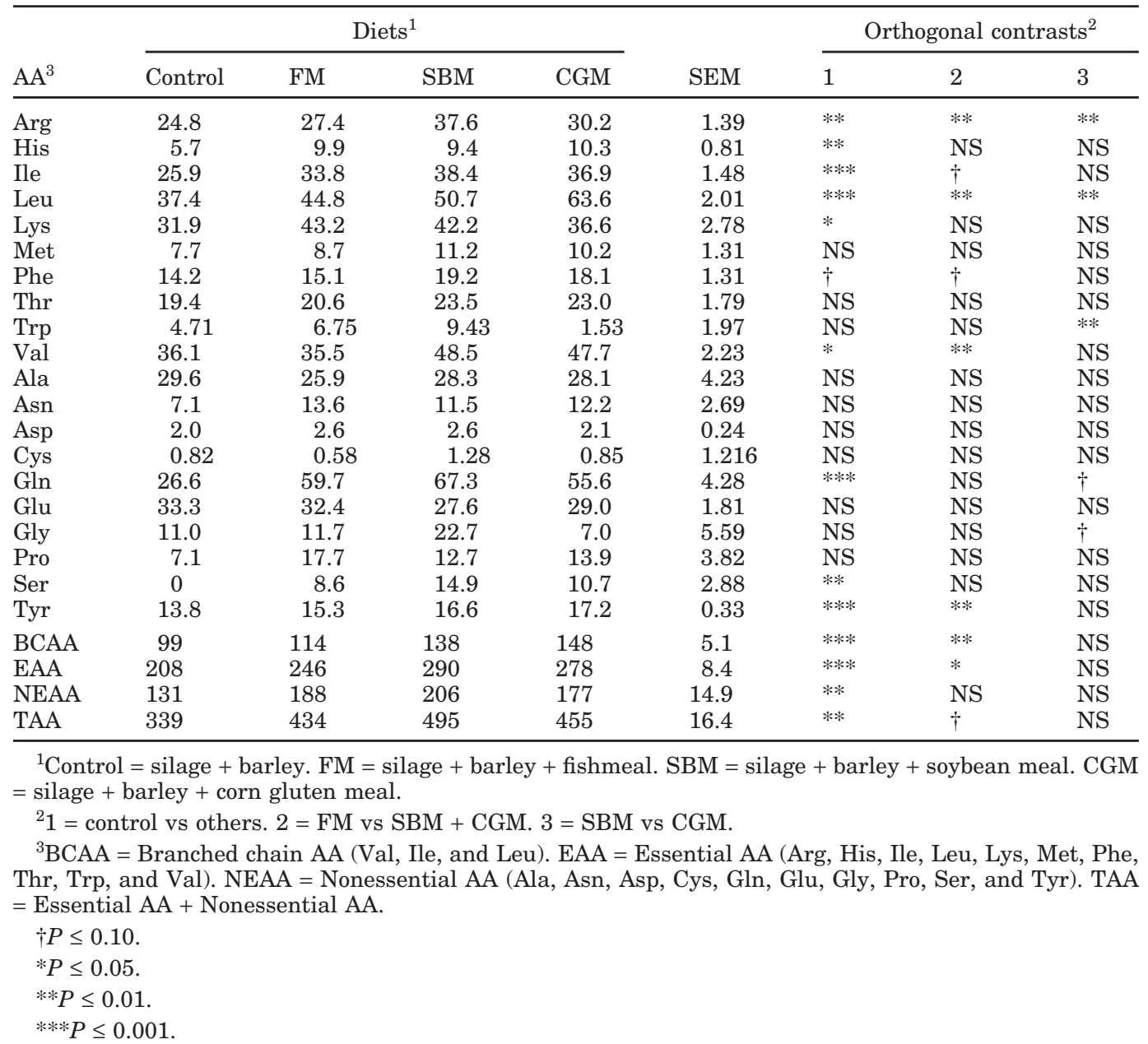

Based on the results mentioned above, it is apparent that production responses can not be solely accompanied by CP content of the basal diet that is consistent with a low correlation $(\mathrm{R}=0.11)$ between $\mathrm{CP}$ content of the diet and milk protein yield responses to rapeseed meal supplementation for grass silage-cereal based diets (Huhtanen, 1998). Responses to AA infusions and also to rumen protected AA supplementations have been variable both on grass silage (Kim et al., 2000; Korhonen et al., 2002a) and corn and/or alfalfa silage based diets (Robinson, 1996), indicating that despite the similar basal diet AA supply can be either qualitatively or quantitatively different. Thus, high production responses to protein supplementations could be associated with a low AA supply from the basal diet or with an imbalanced AA profile of digested protein in the intestine. Various AA supply due to different RUP concentration between protein supplements is also the most plausible explanation for the observation that cows benefited more from CGM and FM supplementations than from SBM supplementation. Furthermore, when both silage and barley were replaced with protein feeds in the current study, a smaller reduction in dietary energy content may have occurred compared to reduction associated with replacing only energy concentrates. Thus, the user of AA as an energy substrate may have been lower. This, together with the adequacy of estimated supply of energy across the treatments, may also have boosted nutrient metabolism in the mammary gland, since protein-energy interrelationship plays a decisive role in directing nutrients between body tissues and nutrient utilization by the mammary gland (Oldham, 1984).

Unchanged DMI (Table 2) and rumen fermentation parameters (Table 3) across the treatments suggest that depression in milk fat concentration for the supplemented diets compared with the control diet (Table 2) was most probably associated with a dilution effect, i.e., synthesized fat was secreted into a large amount of milk. Decreased milk lactose concentration in supplemented diets agrees with Spain et al. (1990), Broderick (1992), and Heikkilä et al. (1998). 
Table 8. Least squares means for mammary extractions ${ }^{1}$ of AA (\%).

\begin{tabular}{|c|c|c|c|c|c|c|c|c|}
\hline \multirow[b]{2}{*}{$\mathrm{AA}^{4}$} & \multicolumn{4}{|c|}{ Diets $^{2}$} & \multirow[b]{2}{*}{ SEM } & \multicolumn{3}{|c|}{ Orthogonal contrasts ${ }^{3}$} \\
\hline & Control & $\mathrm{FM}$ & SBM & CGM & & 1 & 2 & 3 \\
\hline Arg & 24.8 & 27.4 & 37.4 & 30.2 & 1.39 & NS & $*$ & NS \\
\hline His & 49.9 & 51.4 & 36.1 & 49.3 & 6.37 & NS & NS & NS \\
\hline Ile & 31.8 & 30.8 & 34.6 & 44.9 & 1.34 & $*$ & $* *$ & $* *$ \\
\hline Leu & 54.6 & 49.4 & 53.2 & 40.8 & 1.65 & $* *$ & NS & $* *$ \\
\hline Lys & 51.7 & 44.9 & 47.6 & 60.3 & 2.68 & NS & $*$ & $*$ \\
\hline Met & 39.1 & 35.5 & 58.2 & 53.3 & 7.53 & NS & $\dagger$ & NS \\
\hline Phe & 29.8 & 41.5 & 41.8 & 35.3 & 2.89 & $*$ & NS & NS \\
\hline Thr & 18.3 & 18.9 & 22.1 & 25.4 & 3.29 & NS & NS & NS \\
\hline Trp & 11.9 & 16.7 & 21.7 & 3.5 & 5.45 & NS & NS & $\dagger$ \\
\hline Val & 25.9 & 19.6 & 26.0 & 29.9 & 1.64 & NS & $* *$ & NS \\
\hline Ala & 10.2 & 9.4 & 10.6 & 11.5 & 1.32 & NS & NS & NS \\
\hline Asn & 13.6 & 21.7 & 17.4 & 18.7 & 5.26 & NS & NS & NS \\
\hline Asp & 34.6 & 40.9 & 43.2 & 39.3 & 3.57 & NS & NS & NS \\
\hline Cys & 5.5 & 2.8 & 4.5 & 3.8 & 5.03 & NS & NS & NS \\
\hline Gln & 9.3 & 19.4 & 21.8 & 19.4 & 1.36 & $* * *$ & NS & NS \\
\hline Glu & 71.1 & 75.5 & 68.9 & 75.4 & 1.66 & NS & NS & $*$ \\
\hline Gly & 1.3 & 3.4 & 6.5 & 2.3 & 1.61 & NS & NS & NS \\
\hline Pro & 12.7 & 18.6 & 12.2 & 10.7 & 4.86 & NS & NS & NS \\
\hline Ser & 0.7 & 7.1 & 13.1 & 9.8 & 2.51 & $*$ & NS & NS \\
\hline Tyr & 25.7 & 37.4 & 35.0 & 29.3 & 2.00 & $* *$ & $\dagger$ & $\dagger$ \\
\hline BCAA & 34.5 & 29.8 & 34.9 & 37.3 & 1.46 & NS & $* *$ & NS \\
\hline EAA & 32.6 & 31.2 & 35.7 & 37.8 & 1.44 & NS & * & NS \\
\hline NEAA & 9.9 & 14.4 & 15.6 & 13.8 & 1.39 & $*$ & NS & NS \\
\hline TAA & 17.3 & 20.7 & 23.1 & 22.5 & 1.37 & $*$ & NS & NS \\
\hline
\end{tabular}

\footnotetext{
${ }^{1}$ Arteriovenous difference/arterial concentration.

${ }^{2}$ Control $=$ silage + barley. FM $=$ silage + barley + fishmeal. $\mathrm{SBM}=$ silage + barley + soybean meal. CGM $=$ silage + barley + corn gluten meal.

${ }^{3} 1=$ control vs others. $2=$ FM vs SBM + CGM. $3=$ SBM vs CGM.

${ }^{4} \mathrm{BCAA}=$ Branched chain AA (Val, Ile, and Leu). EAA = Essential AA (Arg, His, Ile, Leu, Lys, Met, Phe, Thr, Trp, and Val). NEAA = Nonessential AA (Ala, Asn, Asp, Cys, Gln, Glu, Gly, Pro, Ser, and Tyr). TAA $=$ Essential AA + Nonessential AA.

$\dagger P \leq 0.10$.

$* P \leq 0.05$.

$* * P \leq 0.01$.

$* * * P \leq 0.001$.
}

\section{Rumen Fermentation and Diet Digestibility}

Rumen fermentation pattern (Table 3) with a fairly low proportion of propionate in total VFA was typical to that observed for cows fed grass silage and cerealbased concentrate (Huhtanen, 1998). Rumen ammonia concentration has generally increased with protein supplementation for all types of basal diets due to a higher $\mathrm{N}$ intake. A slightly lower ammonia concentration for diet CGM than that for diets FM and SBM was most probably a result of reduced supply of substrate in the rumen for microbial $\mathrm{N}$ degradation due to a lower RDP concentration in CGM compared to SBM and FM. Similar rumen ammonia concentrations for diets FM and SBM despite the lower ruminal digestibility of FM than SBM indicate variable utilization of supplementary $\mathrm{N}$ by rumen microbes, i.e., bacteria may have used ammonia, AA, and peptides in a different manner as substrates for microbial protein synthesis.
Total $\mathrm{N}$ digestibility of the basal diet (Table 3) was lower than that previously observed (Vanhatalo et al., 1999; Korhonen et al., 2000; Huhtanen et al., 2002). This discrepancy may be associated with a variable nutrient supply from the basal diet attributed to $\mathrm{CP}$ content of the basal diet and a different quality of grass silage. Enhanced total tract $\mathrm{N}$ digestibility for supplemented diets compared with that for the control diet and differences in ruminal digestibility suggest that $\mathrm{N}$ flowing to the lower digestive tract was more digestible in the intestine for diets supplemented with protein feeds. This is supported by the observations that proportion of $\mathrm{N}$ excreted in the feces of the $\mathrm{N}$ flowing into the omasum appeared to be higher for the control diet (50\%) compared with diets supplemented with protein feeds (FM; 42\%, SBM; 45\%, and CGM; 43\%). Enhanced ruminal OM digestibility for the supplemented diets may arise from increased activity and pool size of ruminal bacteria. Increased NDF digestibility across the supple- 
Table 9. Least squares means for mammary uptake of AA ( $\mathrm{g} / \mathrm{kg}$ of milk).

\begin{tabular}{|c|c|c|c|c|c|c|c|c|}
\hline \multirow[b]{2}{*}{$\mathrm{AA}^{3}$} & \multicolumn{4}{|c|}{ Diets $^{1}$} & \multirow[b]{2}{*}{ SEM } & \multicolumn{3}{|c|}{ Orthogonal contrasts $^{2}$} \\
\hline & Control & FM & SBM & CGM & & 1 & 2 & 3 \\
\hline Arg & 3.13 & 3.40 & 3.91 & 3.19 & 0.295 & NS & NS & NS \\
\hline His & 0.63 & 1.11 & 0.88 & 0.98 & 0.105 & $*$ & NS & NS \\
\hline Ile & 2.61 & 3.21 & 3.04 & 2.94 & 0.139 & $* *$ & NS & NS \\
\hline Leu & 3.70 & 4.25 & 3.98 & 5.07 & 0.127 & $* *$ & $* *$ & $* *$ \\
\hline Lys & 3.45 & 4.56 & 3.70 & 3.25 & 0.359 & NS & $*$ & NS \\
\hline Met & 0.94 & 0.92 & 0.98 & 0.93 & 0.189 & NS & NS & NS \\
\hline Phe & 1.66 & 1.78 & 1.89 & 1.81 & 0.086 & NS & NS & NS \\
\hline Thr & 1.70 & 1.72 & 1.69 & 1.66 & 0.228 & NS & NS & NS \\
\hline Trp & 0.84 & 1.13 & 1.40 & 0.20 & 0.313 & NS & NS & * \\
\hline Val & 3.05 & 2.90 & 3.42 & 3.41 & 0.252 & NS & NS & NS \\
\hline Ala & 1.74 & 1.55 & 1.50 & 1.54 & 0.286 & NS & NS & NS \\
\hline Asn & 0.80 & 1.46 & 1.07 & 1.10 & 0.322 & NS & NS & NS \\
\hline Asp & 0.20 & 0.24 & 0.20 & 0.17 & 0.024 & NS & $\dagger$ & NS \\
\hline Cys & 0.08 & 0.03 & 0.11 & 0.07 & 0.115 & NS & NS & NS \\
\hline Gln & 3.45 & 7.72 & 7.20 & 6.08 & 0.683 & $* *$ & NS & NS \\
\hline Glu & 3.82 & 3.39 & 2.43 & 2.58 & 0.329 & $*$ & $\dagger$ & NS \\
\hline Gly & 0.09 & 0.13 & 0.24 & 0.08 & 0.064 & NS & NS & NS \\
\hline Pro & 0.74 & 1.43 & 0.86 & 0.99 & 0.296 & NS & NS & NS \\
\hline Ser & -0.07 & 0.63 & 0.94 & 0.67 & 0.250 & $*$ & NS & NS \\
\hline Tyr & 1.91 & 2.00 & 1.80 & 1.90 & 0.118 & NS & NS & NS \\
\hline BCAA & 9.4 & 10.4 & 10.4 & 11.4 & 0.46 & $* * *$ & $* *$ & $\dagger$ \\
\hline EAA & 21.7 & 25.0 & 24.9 & 23.4 & 1.24 & $* *$ & NS & NS \\
\hline NEAA & 12.7 & 18.6 & 16.4 & 15.2 & 1.77 & $\dagger$ & NS & NS \\
\hline TAA & 34.5 & 43.6 & 41.3 & 38.6 & 2.78 & $*$ & NS & NS \\
\hline \multicolumn{9}{|c|}{${ }^{1}$ Control $=$ silage + barley. $\mathrm{FM}=$ silage + barley + fishmeal. $\mathrm{SBM}=$ silage + barley + soybean meal. $\mathrm{CGM}$} \\
\hline \multirow{2}{*}{\multicolumn{9}{|c|}{$\begin{aligned}= & \text { silage }+ \text { barley }+ \text { corn gluten meal. } \\
& { }^{2} 1=\text { control vs others. } 2=\text { FM vs SBM }+ \text { CGM. } 3=\text { SBM vs CGM. }\end{aligned}$}} \\
\hline & & & & & & & & \\
\hline \multicolumn{9}{|c|}{$\begin{array}{l}{ }^{2} 1=\text { control vs others. } 2=\mathrm{FM} \text { vs SBM }+ \text { CGM. } 3=\mathrm{SBM} \text { vs CGM. } \\
{ }^{3} \mathrm{BCAA}=\text { Branched chain AA (Val, Ile, and Leu). EAA = Essential AA (Arg, His, Ile, Leu, Lys, Met, Phe }\end{array}$} \\
\hline \multirow{2}{*}{\multicolumn{9}{|c|}{$\begin{array}{l}\text { Thr, Trp, and Val). NEAA = Nonessential AA (Ala, Asn, Asp, Cys, Gln, Glu, Gly, Pro, Ser, and Tyr). TAA } \\
\text { = Essential AA + Nonessential AA. }\end{array}$}} \\
\hline \multirow{2}{*}{\multicolumn{9}{|c|}{$\begin{aligned}= & \text { Essential A } \\
& \dagger P \leq 0.10\end{aligned}$}} \\
\hline & & & & & & & & \\
\hline \multicolumn{9}{|c|}{$* P \leq 0.05$} \\
\hline \multicolumn{9}{|c|}{$* * P \leq 0.01}$. \\
\hline
\end{tabular}

mented diets compared to the control diet may arise either from increased nutrient supply associated with an enhanced activity of fibrolytic bacteria or from increased postruminal NDF digestion related to variation in composition of dietary NDF. The ratios of ruminal to total NDF digestibility were 0.87 and 0.85 for the control diet and across the supplemented diets, respectively supporting the latter explanation.

\section{Nitrogen and AA Supplies}

Omasal NAN flow. Increasing the RUP supply is the most common feeding strategy that have been used to enhance the amount of protein and AA available for absorption in ruminants. Increased total NAN flow for supplemented diets (Table 4) was consistent with this and also with an expectation that in the presence of adequate supply of RDP, higher RUP supply enhance postruminal $\mathrm{N}$ flow. Unchanged microbial NAN flow and microbial protein synthesis (MPS) across the treatments (Table 4) indicate that RDP supply was not a limiting factor in MPS. Decreased total NAN flow due to a lowered microbial NAN flow with higher RUP supply was associated with an unchanged milk protein yield in most studies reported by Santos et al. (1998). This emphasizes the importance of adequate supply of $\mathrm{RDP}$ if the target is to maximize protein supply and milk protein yield. In accordance with this, MPS was similar for the basal diet consisting of a grass silage and cereal, for that supplemented with urea and for that supplemented with rapeseed meal (Ahvenjärvi et al., 1999) and also for diets consisting of grass silage alone and grass silage supplemented with barley and/ or rapeseed meal (Ahvenjärvi et al., 2002). In these studies, the efficiency of MPS (Table 4) was also comparable to that currently observed suggesting that on grass silage cereal based diets RDP is not generally a limiting factor in MPS.

High contribution of microbial NAN flow to total omasal NAN flow $(69 \%)$ for the control diet (Table 4) is consistent with other studies using similar basal diets (Ahvenjärvi et al., 1999; Ahvenjärvi et al., 2002; Korho- 
Table 10. Least squares means for mammary plasma flow, concentrations, arteriovenous differences, extractions ${ }^{1}$ and uptakes of plasma energy metabolites, urea, and insulin.

\begin{tabular}{|c|c|c|c|c|c|c|c|c|}
\hline & \multicolumn{4}{|c|}{$\operatorname{Diets}^{2}$} & SEM & \multicolumn{3}{|c|}{ Orthogonal contrasts ${ }^{3}$} \\
\hline \multicolumn{9}{|l|}{ Mammary plasma flow } \\
\hline $\mathrm{L} / \mathrm{kg}$ of milk & 780 & 730 & 602 & 611 & 44.2 & $*$ & $\dagger$ & NS \\
\hline \multicolumn{9}{|l|}{ Glucose, mmol/L } \\
\hline Arterial concentration & 3.40 & 3.18 & 3.17 & 3.16 & 0.069 & $*$ & NS & NS \\
\hline Uptake, $\mathrm{g} / \mathrm{kg}$ of milk & 83.5 & 96.5 & 73.1 & 74.0 & 8.47 & NS & $\dagger$ & NS \\
\hline \multicolumn{9}{|l|}{$\mathrm{NEFA}, \mu \mathrm{mol} / \mathrm{L}$} \\
\hline Arterial concentration & 87 & 110 & 120 & 99 & 19.0 & NS & NS & NS \\
\hline Arteriovenous difference & -18 & -11 & -8 & -13 & 8.9 & NS & NS & NS \\
\hline Extraction, \% & -23 & -22 & -19 & -19 & 7.0 & NS & NS & NS \\
\hline \multicolumn{9}{|l|}{ BHBA, mmol/L } \\
\hline Arterial concentration & 0.78 & 0.82 & 0.78 & 0.83 & 0.058 & NS & NS & NS \\
\hline Arteriovenous difference & 0.91 & 0.78 & 0.70 & 0.93 & 0.099 & NS & NS & NS \\
\hline Extraction, \% & 75.1 & 70.3 & 70.3 & 76.6 & 2.36 & NS & NS & NS \\
\hline Insulin, $\mu \mathrm{U} / \mathrm{ml}$ & 8.30 & 7.40 & 7.28 & 7.38 & 0.356 & $\dagger$ & NS & NS \\
\hline Urea, $\mu \mathrm{mol} / \mathrm{L}$ & 2152 & 4665 & 4732 & 4322 & 148.3 & $* * *$ & NS & $\dagger$ \\
\hline
\end{tabular}

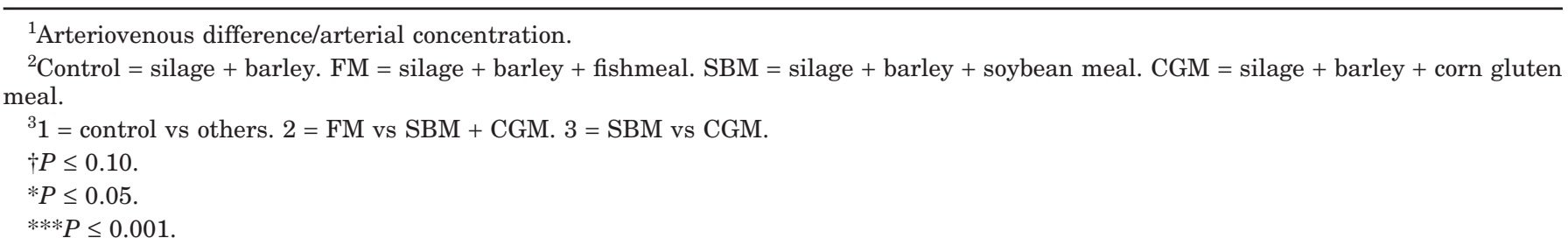

nen et al., 2002a). This together with absence of dietary effect on microbial AA profile highlight the role of RUP in manipulation of AA supply, i.e., the manipulated postruminal AA supply and the composition of AA absorbed from the intestine can be achieved by manipulating the AA profile of dietary protein and the proportions of RUP and microbial protein in postruminal flow rather than affecting the AA profile of microbial protein.

In agreement with Santos et al. (1984), and Titgemeyer et al. (1989), SBM supplementation resulted in a lower total NAN flow associated with a smaller increase in dietary NAN compared to FM and CGM supplementations. These differences together with the highest $\mathrm{N}$ intake (Table 4), numerically lowest efficiency of MPS, and the highest ruminal $\mathrm{N}$ digestibility for diet SBM suggest a higher $\mathrm{N}$ loss in the rumen for diet SBM that is in accordance with a lower RUP concentration in SBM than in FM and CGM (Santos et al., 1998).

Omasal AA flow. Total AA flows (Table 5) are consistent with total NAN flows; lowest flow for diet SBM and highest for diet CGM and were associated with an increased dietary AA flow and an unchanged microbial AA flow. That TAA flow was lower for diet SBM than for diets FM and CGM is consistent with the fact that SBM protein is more rumen degradable than the other proteins and, therefore, provides less RUP.

Flows (g/kg DMI) of TAA (83 vs 117 ), EAA (39.5 vs 58.8 ), His (1.9 vs 3.0), Met (2.4 vs 3.3), Leu (6.7 vs 10.3 ), and Lys (5.4 vs 7.8 ) for the control diet were lower than the flows previously observed for a grass silage-cereal diet (Korhonen et al., 2000; Korhonen et al., 2002a,b). A high ruminal $\mathrm{N}$ loss in the current study is one potential explanation for these differences. According to Oldham (1984) the ratio of AA-N to ME (g/MJ) supply should be close to 1.2 in high yielding dairy cows. These ratios calculated based on the measured AA flow and DOMI, and using a value of $85 \%$ for intestinal AA digestibility were 1.03, 1.14, 1.04, 1.24 for diets control, FM, SBM, and CGM, respectively, indicating the deficiency of AA supply related to energy supply. Based on the speculation of Oldham (1984) this situation may enable cows to respond highly to increased AA supply. The role of AA supply as a limiting factor for milk production is further supported by a linear positive relationship between TAA flow and milk protein yield $\left(\mathrm{R}^{2}=0.71, \mathrm{n}=\right.$ 16). The positive relationship between His flow and 
protein yield $\left(R^{2}=0.71, \mathrm{n}=16\right)$ was higher than the respective relationships for Met $\left(R^{2}=0.64, n=16\right)$, Lys $\left(\mathrm{R}^{2}=0.60, \mathrm{n}=16\right)$, and Leu $\left(\mathrm{R}^{2}=0.56, \mathrm{n}=16\right)$. Thus, it appears that His was the most probable candidate for the first limiting AA for milk production.

The relative flow ratios of His to Met, His to Leu, and His to Lys were $0.79,0.28$, and 0.35 . The respective values previously observed have varied in range of 0.81 to $1.09,0.28$ to 0.31 , and 0.37 to 0.42 (Korhonen et al., 2000; 2002a,b). These values are consistent with suggestion that despite the similar basal diet, AA supply can be different (Kim et al., 2000, 2001b; Korhonen et al., 2002b). Based on these values it is apparent that variation is highest in the ratio of His to Met.

Significant or numerical differences in individual AA flows between diets SBM and CGM (Table 5) are in accordance with observations of Santos et al. (1984) and Titgemeyer et al. (1989), except for a higher Arg flow on diet CGM and unchanged His flow. Differences in flows of EAA, Arg, Lys, Met, and Val between diets FM and SBM are also in agreement with observations of Keery et al. (1993). Amino acid profiles of the ingested diets may be an explanation for these variations. In spite of a fairly small inclusion (6\% to $10 \%$ of the total DM) of protein supplements into the diet, AA profiles of protein feeds reflected to postruminal AA flow that is consistent with increased flows of dietary NAN for supplemented diets and also differences in AA profiles between microbial protein and feedstuffs (Table 1).

Differences in Lys and Met flows (Table 5) associated with differences in milk and milk protein yields (Table 2 ) between the treatments support the previously presented conclusions that Met or Lys are not the first limiting AA for milk production on grass silage-cereal based diets (Varvikko et al., 1999). Furthermore, based on milk production and Leu flow, neither Leu seemed to be a limiting AA for milk production. According to Lys and Leu flows and milk protein yields for diets FM and CGM, it appears that supply of Lys may have compensated Leu supply and vice versa. The mean mammary uptake to output ratios across the treatments for Leu (1.19) and for Lys (1.33) are consistent with this because Leu and Lys are used as $\mathrm{C}$ and $\mathrm{N}$ donors for NEAA synthesis.

Soybean meal supplementation increased omasal canal His flow by $2.2 \mathrm{~g} / \mathrm{d}$ compared to the control diet (Table 5). This together with a fairly low His flow for the control diet suggest that a poorer milk protein yield response to SBM than to FM or CGM could be related to a limited supply of His. This is supported by the His concentration in milk protein. That is, expecting that His digestibility was similar for all treatments, increased His flow would not have been sufficient to increase protein synthesis more than that observed. On

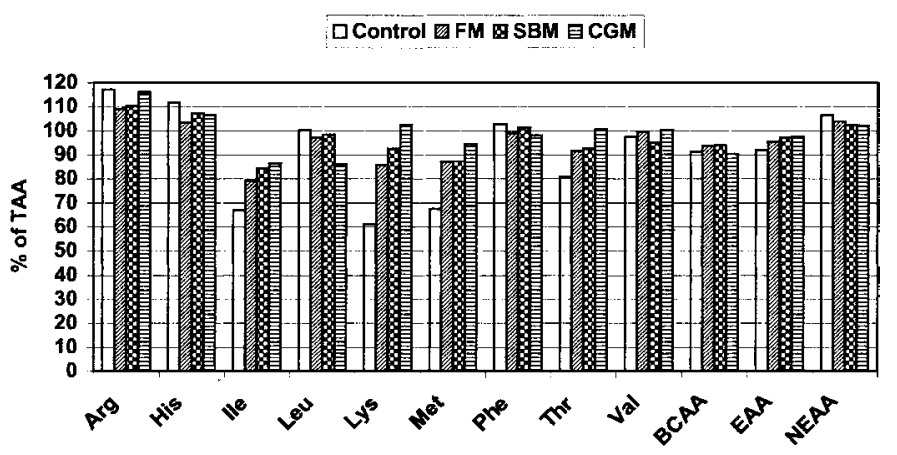

Figure 1. Relative ruminal AA degradabilities (AA degradability/ TAA degradability), Control = silage + barley, $\mathrm{FM}=$ silage + barley + fishmeal, $\mathrm{SBM}=$ silage + barley + soybean meal, CGM = silage + barley + corn gluten meal.

the other hand, Kim et al. (2001b) observed a production response to His for a grass silage-cereal based diet but not for a grass silage-cereal based diet supplemented with SBM. They speculated that the margin by which His was first limiting was possibly reduced for diet including SBM and the limiting supply of another AA disrupted the effect of His on milk protein synthesis. In the current study, omasal Met flow was $1.5 \mathrm{~g} / \mathrm{d}$ lower for diet SBM than for the control diet. Thus Met could become the first limiting AA blocking the effect of His. This is supported by Schwab et al. (1976) who concluded based on the results of series of AA infusion studies that the margin between the first and the second limiting $\mathrm{AA}$ can be very small.

Ruminal AA degradability. We calculated ruminal degradability of AA based on AA intake and dietary AA flow (1 - (AA flow - microbial AA flow)/ingested AA) and assumed that all residual AA were of dietary origin. Ruminal AA degradabilities are presented as relative degradability values (AA degradability/TAA degradability) in Figure 1. Of the individual EAA, Arg (1.13), and His (1.07) were more degradable, and Met (0.84), Thr (0.91), Ile (0.79), Leu (0.95), and Lys (0.85) less degradable than the TAA in general when calculated as a mean values across the treatments. These values may be confounded by the contribution of endogenous and protozoal AA. Different values between the treatments (Figure 1) indicate, however, that various protein feeds had different AA degradabilities that is in accordance with observations from rumen incubation (Erasmus et al., 1994) and also with AA flow measurement (Titgemeyer et al., 1989).

\section{Plasma Metabolites}

Plasma concentrations and mammary metabolism of AA. Plasma concentrations of EAA and TAA 
(Table 6) were low compared with previous observations for a similar basal diet (Vanhatalo et al., 1999; Korhonen et al., 2000; Korhonen et al., 2002a). This is consistent with low omasal AA flow (Table 5) and support the low protein status for the control diet. Compared to studies in which His was found to be the first limiting AA for milk protein synthesis (Korhonen et al., 2000; Kim et al., 2001b; Huhtanen et al., 2002), plasma His concentration was lower for the basal diet (Table 6). This together with a lower omasal His flow than those previously observed (Korhonen et al., 2000; 2002a,b) promote the suggestion that His was the first limiting AA for milk production also in the current study.

Increased plasma EAA concentrations for the supplemented diets indicate that protein supplements increased also the supply of AA available for tissue metabolism. In agreement with infusion studies (Kim et al., 2001b; Korhonen et al., 2002a) plasma His concentration was very sensitive to changes in its supply. In contrast to His, plasma concentrations of Met, Ile, Leu, and Phe did not reflect digesta supply. Previous observations (Korhonen et al., 2002a) indicated some antagonism or competition in tissue utilization and absorption between Leu, Ile, Met, and Phe supply. Thus, inconsistency between plasma and digesta concentrations may be associated with metabolism of these AA. Postabsorptive metabolism may also explain the sensitivity of plasma His concentration to His supply, because His was found to be the least oxidized essential AA in the tissues of dairy cows (Black et al., 1990).

In agreement with Mackle et al. (2000), milk protein yield was not related to either arterial concentration $\left(\mathrm{R}^{2}=0.04, \mathrm{n}=16\right)$ or arteriovenous difference $\left(\mathrm{R}^{2}=\right.$ 0.005) of EAA. That such relationships did not exist, support the claim that mammary utilization of AA is not regulated solely by arterial supply and that mammary gland is capable to regulate nutrient uptake according to requirements (Bequette and Backwell, 1997; Korhonen et al., 2000; Mackle et al., 2000). It has also been pointed out that the mammary gland may control the mammary plasma flow in order to regulate uptake of nutrients (Bequette and Backwell, 1997). Differences in plasma flows between the treatments (Table 10) support this. A negative relationship existed between the treatment means of His concentration and treatment means of mammary plasma flow $\left(\mathrm{R}^{2}=0.80, \mathrm{n}=4\right)$. Bequette and Backwell (1997) reported a similar effect of His when they administered either a complete AA mixture or a similar AA mixture without His to goats. Plasma flow also decreased numerically in a previous study with graded levels of abomasally infused His (Korhonen et al., 2000). Thus, it is possible that His may have a function as a regulator of mammary gland blood flow. Variation in mammary extractions of several individual AA (Table 8) and in plasma AA concentrations of the respective AA (Table 6) are consistent with speculations that the mammary gland aims to maintain the uptake of some individual AA commensurate with other AA (Bequette and Backwell, 1997), and indicate that mammary gland tended to regulate AA uptake according to requirements.

Some evidence exists that Leu stimulates protein synthesis and reduces protein breakdown in the tissues (Block et al., 1988). If this is true, then higher protein yields for diets FM and CGM than that for diet SBM would be associated with an increased supply of Leu, since mammary uptake of Leu was higher for diets FM and CGM compared to that for diet SBM.

Concentrations of plasma insulin, energy metabolites, and mammary metabolism of energy metabolites. Plasma glucose concentration for the control diet (Table 10) was higher than that generally observed for the similar basal diet without additional glucose (Miettinen and Huhtanen, 1997; Vanhatalo et al., 1999; Huhtanen et al., 2002) but similar to values previously reported in studies where glucose was abomasally infused at a rate of $250 \mathrm{~g} / \mathrm{d}$ (Korhonen et al., 2000; Korhonen et al., 2002a). This indicates a higher glucose supply from the basal diet in the present study compared with the studies mentioned above and is supported by a low correlation $\left(R^{2}=0.03 n=16\right)$ between AV difference and arterial concentration of glucose.

The effects of AA supplementations either by infusions or by protein feeds on plasma glucose concentration have been variable (Miettinen and Huhtanen, 1997; Mackle et al., 1999). This inconsistency between studies may be related to a variable utilization of glucose by the mammary gland and utilization of NEAA in liver for glucose synthesis. In the current study, the higher glucose supply and reduced glucose concentration for diets supplemented with protein feeds compared with the control treatment suggests that the mammary gland used plasma glucose to meet the increased glucose requirement. In spite of the reduced concentration, it is apparent that mammary gland was able to maintain glucose uptake by increasing extraction. This is consistent with conclusions that mammary glucose uptake is determined by mammary gland biosynthetic activity, availability of other nutrients, and blood flow rather than plasma concentration (Miller et al., 1991). The mean mammary uptake of glucose across treatments was higher (83 vs 68 ) than that previously observed (Vanhatalo et al., 1999; Korhonen et al., 2000; 2002a), mainly due to high uptake values for the diets control and FM (Table 11). These numerically high values may originate from the high plasma flow.

Responses in plasma insulin concentration to increased AA supply have also been variable (Miettinen 
and Huhtanen, 1997) and may be related to variation in plasma glucose concentration. This is consistent with the relationship between plasma glucose and insulin concentration $\left(R^{2}=0.49\right)$. Concentrations of other energy metabolites were comparable to those observed in studies with a similar basal diet and have not generally been affected by the treatments supplying more individual AA or protein (Miettinen and Huhtanen, 1997; Vanhatalo et al., 1999; Korhonen et al., 2000).

In agreement with observations of Miettinen and Huhtanen (1997) and Korhonen et al. (2002a), AV difference of acetate was positively correlated $\left(R^{2}=0.92\right.$, $\mathrm{n}=16$ ) with arterial concentration, indicating that mammary utilization of acetate is dependent on the supply. In contrast to Miettinen and Huhtanen (1997), relationship between mammary uptake of acetate and glucose did not exist in the current study.

\section{Utilization of Supplementary AA}

In the present study, the mean utilizations of incremental TAA and His supply for milk protein synthesis across the supplemented diets were 65 and $85 \%$. The respective values were 43 and $47 \%$ when grass silagebarley based diet was supplemented with rapeseed meal (Korhonen et al., 2002b). Higher utilization of His than that of TAA confirms His deficiency for the control diet, and a high TAA utilization is in accordance with a low AA supply and sufficient energy and glucose supplies from the basal diet. These His utilizations are, however, higher than those observed for infused His (from $20 \%$ to $40 \%$ ) in situations where His has been the first limiting AA for milk production (Korhonen et al., 2000; Kim et al., 2001a).

In studies reported by Kim et al. (2001a), milk protein yield increased up to $6 \mathrm{~g} / \mathrm{d}$ of infused His, but in the second study with a similar basal diet it increased linearly up to $9 \mathrm{~g} / \mathrm{d}$ with simultaneous infusion of Met, Lys, and Trp. Similarly, milk protein yields (Table 2) and postruminal flows of TAA and individual AA (Table 5 ) were different between the supplemented diets, indicating that utilization of AA are also related to the AA profile of absorbed protein. This is supported by conclusion that "simply providing the mammary gland with more AA does not guarantee large increases in the yield of milk protein" (Mackle et al., 1999). The role of AA profile may be associated with mammary gland metabolism, since it has been speculated that AA utilization by the mammary gland is controlled by mammary gland metabolism rather than the nutrient supply (Bequette and Backwell, 1997). Estimated mammary plasma flows (Table 10), AA extractions (Table 8), and slightly different proportions of some of the individual AA of the EAA AV difference (Table 7) support this.
Thus, in the presence of supplementary AA, the mammary gland may be able to maintain constant uptake ratios of individual $\mathrm{AA}$ and also balance the overall $\mathrm{N}$ and $\mathrm{C}$ supplies.

\section{CONCLUSIONS}

This study demonstrated that cows fed a grass silagecereal based diet benefited from protein supplementation that increased flow of RUP, suggesting that in spite of the adequate supply of RDP, microbial protein supply was insufficient to meet protein and AA requirements both quantitatively and qualitatively. Amino acid supply was higher for the diets supplemented with protein feeds because of unchanged microbial protein flow and increased RUP flow. Amino acid supply was lower for SBM diet than CGM and FM diets because of a higher ruminal degradation of SBM. Higher RUP flow and variable AA profiles of protein feeds were also reflected in the omasal canal AA flows. It is apparent that enhanced milk and milk protein yields were associated with increased postruminal individual $\mathrm{AA}$ and TAA supplies, confirming the importance of AA profile of absorbed protein. For the basal diet, His appeared to be the first limiting AA for milk production. A limited supply of Met was the probable reason for a lower milk protein yield response to SBM than that to FM and CGM. Mammary uptake of AA seemed to be regulated by mammary gland metabolism, and mammary glands seemed to be able to control AA uptake to maintain the uptake of some individual AA commensurate with other $\mathrm{AA}$ and also maintain $\mathrm{N}$ and $\mathrm{C}$ balance. One mechanism involved in this process is mammary blood flow.

\section{ACKNOWLEDGMENTS}

This work was financially supported by Rehuraisio Ltd., Raisio, Finland. The authors thank Mrs. Aino Matilainen and her staff for technical assistance and Mr. Vesa Toivonen and his staff for chemical analyses.

\section{REFERENCES}

Ahvenjärvi, S., A. Vanhatalo, P. Huhtanen, and T. Varvikko. 1999. Effects of supplementation of a grass silage and barley diet with urea, rapeseed meal and heat-moisture-treated rapeseed cake on omasal digesta flow and milk production in lactating dairy cows. Acta. Agric. Scand., Sect. A, Animal Sci. 49:179-189.

Ahvenjärvi, S., A. Vanhatalo, P. Huhtanen, and T. Varvikko. 2000. Determination of reticulo-rumen and whole stomach digestion in lactating cows by omasal or duodenal sampling. Br. J. Nutr. 83:67-77.

Ahvenjärvi, S., A. Vanhatalo, and P. Huhtanen. 2002. Supplementing barley or rapeseed meal to dairy cows fed grass-red clover silage: 1. Rumen degradability and microbial flow. J. Anim. Sci. 80:2176-2187.

Bequette, B. J., and F. R. C. Backwell. 1997. Amino acid supply and metabolism by the ruminant mammary gland. Br. J. Nutr. 56:593-605. 
Black, A., R. S. Anand, M. L. Bruss, C. A. Brown, and J. A. Nakagiri. 1990. Partition of amino acids in lactating dairy cows: Oxidation to carbon dioxide. J. Nutr. 120:700-710.

Block, K. P. 1988. Interactions among leucine, isoleucine, and valine with special reference to the branched-chain amino acid antagonism. Pages 229-244 in Absorption and Utilization of Amino Acids. Vol. 1. M. Friedman, ed. CRC Press, Boca Raton, FL.

Broderick, G. A. 1992. Relative value of fish meal versus solvent soybean meal for lactating dairy cows fed alfalfa silage as sole forage. J. Dairy Sci. 75:174-183.

Chamberlain, D. G., P. A. Martin, and S. Robertson. 1989. Optimizing compound feed use in dairy cows with high intakes of silage. Pages 245-263 in Recent Advances in Animal Nutrition. W. Haresign and D. J. A. Cole, ed. Butterworths, London.

Choi, C. W., A. Vanhatalo, and P. Huhtanen. 2002. Concentration and estimated flow of soluble non-ammonia nitrogen entering the omasum of dairy cows as influenced by different protein supplements. Agric. Food Sci. Fin. 11:79-91.

Erasmus, L. J., P. M. Botha, and C. W. Cruywagen. 1994. Amino acid profile and intestinal digestibility in dairy cows of rumenundegradable protein from various feedstuffs. J. Dairy Sci. $77: 541-551$

Heikkilä, T., V. Toivonen, and P. Huhtanen. 1998. Effects of and interaction between the extent of silage fermentation and protein supplementation in lactating dairy cows. Agr. Food Sci. Fin. 7:329-343.

Huhtanen, P. 1998. Supply of nutrients and productive responses in dairy cows given diets based on restrictively fermented silage. Agr. Food Sci. Fin. 7:219-250.

Huhtanen, P., A. Vanhatalo, and T. Varvikko. 2002. Effects of abomasal infusions of histidine, glucose, and leucine on milk production and plasma metabolites of dairy cows fed grass silage diets. J. Dairy Sci. 85:204-216.

Keery, C. M., H. E. Amos, and M. A. Froetschel. 1993. Effects of supplemental protein source on intraruminal fermentation, protein degradation, and amino acid absorption. J. Dairy Sci. 76:514-524.

Kim, C. H., J. J. Choung, and D. G. Chamberlain. 2000. Variability in the ranking of the three most-limiting amino acids for milk protein production in dairy cows consuming grass silage and a cereal-based supplement containing feather meal. J. Sci. Food. Agric. 80:1386-1392.

Kim, C. H., J. J. Choung, and D. G. Chamberlain. 2001a. Estimates of the efficiency of transfer of L-histidine from blood to milk when it is the first-limiting amino acid for secretion of milk protein in the dairy cow. J. Sci. Food Agric. 81:1150-1155.

Kim, C. H., J. J. Choung, and D. G. Chamberlain. 2001b. Responses of milk production to the intravenous infusion of amino acids in dairy cows given diets of grass silage and cereal-based supplements. J. Anim. Physiol. a. Anim. Nutr. 85:293-300.

Korhonen, M., A. Vanhatalo, and P. Huhtanen. 2000. Responses to graded postruminal doses of histidine in dairy cows fed grass silage diets. J. Dairy Sci. 83:2596-2608.

Korhonen, M., A. Vanhatalo, and P. Huhtanen. 2002a. Evaluation of isoleucine, leucine, and valine as a second limiting amino acid for milk production in dairy cows fed grass silage diet. J. Dairy Sci. 85:1535-1545.

Korhonen, M., S. Ahvenjärvi, A. Vanhatalo, and P. Huhtanen. 2002b. Supplementing barley or rapeseed meal to dairy cows fed grassred clover silage: 2. Amino acid profile of microbial fractions. J. Anim. Sci.80:2188-2196.
Mackle, T. R., D. A. Dwyer, and D. E. Bauman. 1999. Effects of branched-chain amino acids and sodium caseinate on milk protein concentration and yield from dairy cows. J. Dairy Sci. 82:161-171.

Mackle, T. R., D. A. Dwyer, K. L. Ingvartsen, P. Y. Chouinard, D. A. Ross, and D. E. Bauman. 2000. Effects of insulin and postruminal supply of protein on use of amino acids by the mammary gland for milk protein synthesis. J. Dairy Sci. 83:93-105.

Miettinen, H., and P. Huhtanen. 1997. Effects of silage fermentation and postruminal casein supplementation in lactating dairy cows. 2. Energy metabolites and plasma amino acids. J. Sci. Food and Agric. 74:450-458.

Miller, P. S., B. L. Reis, C. C. Calvert, E. J. DePeters, and R. L. Baldwin. 1991. Patterns of nutrient uptake by the mammary glands of lactating dairy cows. J. Dairy Sci. 74:3791-3799.

Oldham, J. D. 1984. Protein-energy interrelationships in dairy cows. J. Dairy Sci. 67:1090-1114.

Ørskov, E. R., N. A. Macleod, and D. J. Kyle. 1986. Flow of nitrogen from the rumen and abomasum in cattle and sheep given proteinfree nutrients by intragastric infusions. Br. J. Nutr. 56:241-248.

Robinson, P. H. 1996. Rumen protected amino acids for dairy cattle: What is the future? Anim. Feed Sci. Technol. 19:81-86.

Santos, K. A., M. D. Stern, and L. D. Satter. 1984. Protein degradation in the rumen and amino acid absorption in the small intestine of lactating dairy cattle fed various protein sources. J. Anim. Sci. 58:244-255

Santos, F. A. P., J. E. P. Santos, C. B. Theurer, and J. T. Huber. 1998. Effects of rumen-undegradable protein on dairy cow performance: A 12-year literature review. J. Dairy Sci. 81:3182-3213.

SAS. 1996. User's Guide: Statistics. Version 6.12 Edition. SAS Institute Inc., Cary, NC.

Schwab, C. G., L. D. Satter, and A. B. Clay. 1976. Response of lactating dairy cows to abomasal infusion of amino acids. J. Dairy Sci. 59:1254-1270.

Sloan, B. K., P. Rowlinson, and D. G. Armstrong. 1988. The influence of a formulated excess of rumen degradable protein or undegradable protein on milk production in dairy cows in early lactation. Anim. Prod. 46:13-22.

Spain, J. N., M. D. Alvarado, C. E. Polan, C. N. Miller, and M. L. McGilliard. 1990. Effect of protein source and energy on milk composition in midlactation dairy cows. J. Dairy Sci. 73:445-452.

Titgemeyer, E. C., N. R. Merchen, and L. L. Berger. 1989. Evaluation of soybean meal, corn gluten meal, blood meal and fish meal as sources of nitrogen and amino acids disappearing from the small intestine of steers. J. Anim. Sci. 67:262-275.

Tuori, M., K. Kaustell, J. Valaja, E. Aimonen, E. Saarisalo, and P. Huhtanen. 2000. Rehutaulukotja Ruokintasuositukset. (Feed Tables and Feeding Recommendations). 3rd ed. Yliopistopaino, Helsinki, Finland.

Vanhatalo, A., P. Huhtanen, V. Toivonen, and T. Varvikko. 1999 Response of dairy cows fed grass silage diets to abomasal infusions of histidine alone or in combinations with methionine and lysine. J. Dairy Sci. 82:2674-2685.

Varvikko, T., A. Vanhatalo, T. Jalava, and P. Huhtanen. 1999. Lactation and metabolic responses to graded abomasal doses of methionine and lysine in dairy cows fed grass silage diets. J. Dairy Sci. 82:2659-2673.

Wohlt, J. E., S. L. Chmiel, P. K. Zajac, L. Backer, D. B. Blethen, and J. L. Evans. 1991. Dry matter intake, milk yield and composition, and nitrogen use in Holstein cows fed soybean, fish, or corn gluten meals. J. Dairy Sci. 74:1609-1622. 